\title{
POLICY FOR HIGHER EDUCATION IN BRITAIN
}

$\mathrm{A}^{\mathrm{N}}$ MONG the evidence submitted by the Committee of Vice-Chancellors and Principals of the Universities of the United Kingdom to the Robbins Committee was the declaration that the power to grant degrees should be restricted to teaching bodies*. The heads of universities would greatly regret any suggestion that degree-granting powers should be given to institutions which were merely examining bodies. Even though an individual teacher may not himself examine tho students he has taught, the general body of teachers should be in effective control of the curricula and examinations on which degrees are awarded.

The Committee recommends that colleges of advanced technology should be granted charters enabling them to bestow specified degrees and to enjoy systems of self-government appropriate to this status. With training colleges, however, the Committee recognizes that the obligation to pursue research is in general not recognized as an essential part of the duties of the staff, though there are important exceptions, and some teachers, often in difficult and discouraging circumstances, do pursue their personal studies to high levels. The training in such colleges is inevitably directed towards one profession. If a wider role were contemplated for such colleges or for a selected number of them, it is essential that the student should be given the right to defer his choice of profession, and, in such circumstances, the colleges would presumably move to a situation more akin to that obtaining in the universities where the professional courses for teachers are in most cases limited to a concluding year. The Committee welcomes the willingnoss which many universities have expressed to make wider and more flexible use of the powers, which many of them already possess, to recognize the new three-year training college courses as exempting students from some part of the requirements for a first degree.

Of degree courses, exporiments which are taking place in relation to the master's degree are to be commended, and the Committee believes that the master's degree could in many cases be based on the successful completion of a further course of organized study which does not necessarily involvo rescarch.

The addition of a fourth year to the basic degree course would be an unfortunate step. If a four-year course became normal, universities would be unable to admit as many entrants, and a smaller output of university graduates involved could not be contemplated either in the immediate or in the more distant future. The existing practice wheroby a standard three-year course can, in appropriate circumstances, be followed by a one-year postgraduate course of instruction, is the obvious solution and ought to be further developed.

Wastage-rates, according to the Committee, could not reasonably be expected to be less than 10 per cent. A figure less than this would be capable of the interpretation that selectors were playing for academic safety. There is, however, a number of

* Committee of Vice-Chancellors and Principals of the Universities of the United Kingdom. Memorandum of Evidence to the Committee on Higher Eiducation. Pp. 11. (London: Committce of Vice-Chan- factors likely to operate in the future which would make any prognosis about wastage-rates more than usually difficult. Change and experiment introduce some hazards; the multi-subject honours degree which so many students believe would suit them is not necessarily of an easier standard than the singlesubject degree. Even more important will be the growing number of students coming into the university from backgrounds which have hitherto had no cognizance of universities at all.

In relation to women candidates, the present position is not satisfactory. The difficulties which arise however, are, not directly attributable to the universities. In the main, the girls' schools are less well equipped to bring candidates to the level of university ontrance than are boys' schools. especially in science and mathematics. The universities would welcome more women, particularly in science, and would regret a situation in which the science side became predominantly male and the arts side predominantly female. The employment position is such that many occupations would welcome more women graduates.

It is difficult to say whether the present allocation of time in universities between teaching and research is satisfactory; few teachers can divide their time simply between these two. A large number of teachers is inevitably involved in administration one way or another. These and other sabbatical activities present the university teacher with a problem as to how he should allocate his time. The ideal would be the allocation of one-half the time to teaching and the other to research, including under both headings the administrative work pertinent to them and bearing in mind the fact that the proportions are not equally spread throughout the year, for students are present only during term and much research work is done in vacations.

The Committee's concern is to ensure that the balance between teaching and research is not imperilled by the expansion to 175,000 places. This concern is more urgent because of the increasing impression among the staffs of the univorsities that the Government directs too small a proportion of its research expenditure into the universities. Britain will be the loser if the potential of the universities is not fully exploited because of the failure to provide sufficient resources.

The Committee welcomes the increasing activity of the private foundations with the help of which some of the most interesting experiments in teaching and research over the past few years have taken place. They have, quite properly, refused to support the merely routine activities. Their policy of underwriting the project which has a considerable element of risk has permitted the universities to bo more adventurous than would normally have been the caso. But this policy will be abortive unless the universities are put into a position to take up those projects which prove to bo successful after the exploratory period is over. Similarly, the Committee of Vice-Chancellors and Principals welcomes the continued interest in, and support of, university activitics by the more progressive industrial firms, and particularly those industrial donors who have 
included the arts and social sciences in their benefactions.

The universities in Britain have maintained a high degree of independence in matters of academic planning and general policy. They choose their own students and staff and themselves determine the content of their teaching. Finance and aspects of policy inseparable from finance are rightly the subject of discussion between the universities and the Government. While greater availability of resources at an earlier period would have better enabled the universities to cope with the difficulties that lie immediately ahead, and, in consequence, university initiatives have been restrained, the balance between university freedom and Government control is, broadly speaking, maintained in a satisfactory position.

The Committee also makes recommendations for strengthening the University Grants Committee by the appointment of a full-time deputy chairman.

\section{DEPTH AND TECTONICS AS FACTORS IN REGIONAL METAMORPHISM}

$\mathrm{T}$ HE Geological Society of London held the third of its recently instituted series of symposia at the Royal Institution on November 22, with Prof. S. E. Hollingworth, president of the Society, in the chair.

Prof. H. H. Read opened the symposium with "Some Introductory and Cautionary Remarks" in which he pointed out that the pressures concerned in regional metamorphism may not be related to true crustal depth and that it was not always safe to argue that large vertical movements had occurred where minerals known to form at high pressure were exposed at the surface. This topic was taken up later in the discussion when several speakers argued that tectonic pressures might well exceed load pressure during regional metamorphism and that the experimental evidence concerning the pressure at which minerals such as kyanite crystallized was not in conflict with field evidence which suggested that the mineral could develop rather high in the crust.

Prof. Read and Dr. G. A. Chinner both directed attention to the importance of andalusite as a product of regional metamorphism. Prof. Read suggested that metamorphism of Buchan type characterized by andalusite schists might well prove to be more widespread than the Barrovian sequence. Dr. Chinner discussed the application of synthetic data to pelitic rocks, arguing that the $\mathrm{Al}_{2} \mathrm{SiO}_{5}$ polymorphs are ideal as their phase relationships are independent of the bulk composition of a rock. He suggested that the triple point at which kyanite, sillimanite and andalusite coexist lies in the vicinity of 10-11 kilobars and $500-600^{\circ} \mathrm{C}$., and that is probably the most reliable pressure-temperature indicator available. Dr. Chinner gave a summary of some of the features of the andalusite-sillimanite sequence (Buchan or Abukuma type regional metamorphism), which is often found around metamorphic nodes or 'highs' which develop in a broad sequence of low-grade rock of greenschist or lower amphibolite facies. Gneissic granite or migmatite may occur in the centre of such rocks, examples of which are known from the Abukuma Plateau in Japan, the Cooma and Albury regions of New South Wales and northern Michigan, among other localities. Dr. Chinner suggested that such rocks formed where recrystallization along geothermal gradients of between $15^{\circ} \mathrm{C}$. and $50^{\circ} \mathrm{C}$. per $\mathrm{km}$. had been followed by an abrupt rise in temperature associated with the intrusion of granite or the uprise of 'juvenile' water. Dr. Chinner illustrated his argument with maps of the distribution of kyanite and andalusite in the classic ground in north-east Scotland, where Barrovian and Buchan metamor- phism are developed in neighbouring areas. Dr. Chinner suggested that certain sillimanite rocks in this region had formed after the kyanite and andalusite and that these marked an isobaric rise in temperature which led to the development of migmatite. Dr. Chinner also pointed out that stress-developed pressure might have exceeded depth-load pressure where kyanite-sillimanite sequences had developed

Dr. R. A. Howie directed attention to the evidence for directed pressure which Read and Pitcher had provided in their account of the main Donegal granite, around which kyanite-bearing rocks were developed, and also commented on the possible difficulties in using the andalusite-kyanite-sillimanite triple point, since the fields of stability of the three polymorphs were not separated by lines so much as by bands of indifference.

Dr. Howie referred to the way in which certain changes in the composition of common metamorphic minerals threw light on conditions of metamorphism and mentioned his own work on the $\mathrm{Al}_{2} \mathrm{O}_{3}$ content of orthopyroxenes, which, it will be recalled, he had found to be unusually high in certain granulite facies rocks.

Prof. K. C. Dunham mentioned a striking example of metamorphic inversion caused by shearing stress in which rocks of the albite-epidote amphibolite metamorphic facies overlay green-schist facies rocks which in turn passed downwards into unmetamorphosed rocks. It seemed probable that the highest grade rocks of this sequence have formed at very shallow depths.

Dr. J. Haller provided a fascinating account of metamorphic and migmatitic rocks from eastern Greenland. These are exposed on large unweathered surfaces where it is possible to observe and photograph structures which elsewhere can only be recognized after prolonged geological mapping. As a result of this, Dr. Haller has been able to examine a strip $1,400 \mathrm{~km}$. long within the East Greenland Caledonian fold belt. After describing the general structure and the time-sequence of events which occurred in this orogeny, Dr. Haller went on to discuss the large-scale migmatitic structures. He showed that migmatites had developed both in the sedimentary cover and in the underlying pre-Caledonian crystalline basement. Dr. Haller distinguished a number of syntectonic migmatite masses which he classified as regional doming and locally upwelled masses. The regional bodies are circular to oval masses more than $20 \mathrm{~km}$. in diameter, while the smaller masses measure up to a few kilometres across. Among these, Dr. 